\title{
THE USE OF SUGGESTION SYSTEM IN POLISH ENTERPRISES FROM THE METALLURGICAL INDUSTRY
}

\author{
${ }^{1}$ Szymon T. DZIUBA, ${ }^{2}$ Manuela INGALDI \\ ${ }^{1}$ Wroclaw University of Economics, Faculty of Engineering and Economics, Wroclaw, Poland, EU \\ szymon.dziuba@ue.wroc.pl \\ ${ }^{2}$ Czestochowa University of Technology, Faculty of Management, Czestochowa, Poland, EU \\ manuela.ingaldi@wz.pcz.pl; manuela@gazeta.pl
}

https://doi.org/10.37904/metal.2019.978

\begin{abstract}
Lean Management as well as different management systems require continuous improvement from enterprises. When looking for areas and ways to improve, the Kaizen philosophy, which is based on the principles of common sense, low-cost and implementation of change, should be taken into account. The Kaizen is an integral part of the improvement processes of the products and their quality, processes, organization, what is more, achieving the objectives set by the enterprise depends on the implementation of appropriate systems. One of the important tools of the Kaizen is the system of submitting ideas by employees, called the Suggestion System. The purpose of such a system is to improve the workplace of an employee or other areas and processes in an enterprise. A suggestion can be made by each employee. The metallurgical industry is very specific. Machines and workstations are used in most cases $24 / 7$, and their work is carried out in a continuous system. It should be emphasized that larger changes and improvement in this case require large financial outlays and often shutdown of machines, therefore the Suggestion System may prove to be very useful. The purpose of the article was to check the applicability of the Suggestion System for quality improvement in Polish enterprises from the metallurgical industry. Particular attention was focused on showing the diversity in the use of this tool by different age groups of employees. In the empirical studies, voluntary interviews with management and staff were used.
\end{abstract}

Keywords: Improvement, Lean Management, Kaizen, Suggestion System

\section{INTRODUCTION}

Modern management and its instruments, including lean management and various types of management systems, are based on continuous improvement [1]. Deming created his PDCA cycle, a method used for continuous improvement [2]. The Kaizen philosophy with its main goal being that large outcomes are caused by many small changes accumulated over time, is inherent in continuous improvement. Kaizen is often understood as small changes. Actually, Kaizen means that everyone should be involved in the process of improvement. Kaizen philosophy is inherent in the processes of quality and product improvement in enterprises, whereas the achievement of the set goals depends on implementation of specific systems [3]. Employees are one of the most important resources of the company. Unfortunately, they are often underestimated and their main task is to listen to what the boss says and follow his or her instructions. It should be noted that unrealized creativity of employees is a wasted organizational resource. According to the Japanese approach, despite the existing and used standards, it is natural for employees to report solutions to improve them. This is achieved by the so-called Suggestions System. Modern companies notice the potential of their employees and attempt to utilize it effectively. Masaaki Imai stated that the Suggestions System is an integral part of continuous improvement oriented towards the individual and thus towards the employee [4].

These employees do not only have the best knowledge, but they are often able to identify how individual processes can be improved because they have the best contact with them [5]. 
Effective use of the system is possible only if the adequate method to notify the ideas by employees is created [6]. Therefore, many enterprises are implementing special organizational solutions in the form of formal programs. Programs of employee's suggestions, based on the experience and involvement of staffs, noticeably contribute to facilitation of the processes and organizational problems, which points to their value. Furthermore, there are more benefits, with all matching the idea of the improvement of current status [7]. Through suggestions from employees, continuous improvement is a gradual and continuous process since one small idea is added to another, which results in a big improvement. This is something that every employee can participate in, using common sense, in order to make logical improvements. A continuous stream of minor improvements flowing from all employees activates a powerful force [8]. The suggestions system makes it possible to delegate responsibility for the workplace to individual employees. This impacts on staff motivation, productivity of activities, and the flow of practical knowledge in the organization, which is obtained directly from the line workers. The Suggestions System ensures an appropriate working atmosphere among employees and a sense that each employee can contribute to the development of the company [9].

Very important elements which help the suggestion system function properly is a transparent and comprehensive rules of notifying the facilitations and the simplified sheet for suggestions. Mutual exchange of thoughts and information became the field for creation of innovative solutions in problematic areas. The metallurgical industry is an important sector yet often overlooked in terms of the use of the Suggestions System. It is an industry where huge machines are often used during various production processes. They often operate in a continuous system. Any changes in such an equipment require not only huge financial expenditure but also switching off the machines for a specific time, which represents a loss from the standpoint of production. If the machine does not operate, it does not make money. In many Polish steel companies, especially smaller ones, production equipment is obsolete and often breaks down. The use of the Suggestions System in this case does not only provide a useful solution, but it is also inexpensive. The experience and knowledge of employees can be fully utilized in this way. The aim of the article was to verify and apply the suggestions system for quality improvement in steel companies in Poland. The particular focus was on showing the variation in the use of this tool by different age groups of employees. The empirical examinations were based on free-form interviews with managers and employees in the companies.

\section{METHODOLOGY}

The study concerned the use of the Suggestions System in the enterprises of the steel sector in Poland. Three steel companies that are not linked with each other (e.g. they do not belong to the same consortium and do not have the same owner) were selected to avoid the likelihood of using the same suggestions System. First and foremost, empirical examinations were based on free-form interviews with managers and employees. The survey analyzed the suggestions from the years 2013-2018 in three companies. The particular focus was on showing the variation in the use of this tool by employees at different age. A method based on case study was employed due to the qualitative character of the research problem. The participants were employees from three steel sector companies that belonged to the same corporation.

\section{SUGGESTION SYSTEMS IN THE RESEARCH OBJECTS}

All the three companies studied have implemented Suggestions Systems. In these enterprises, the goal and area which should and can concern the Suggestion System was determined. Its priority task is to initiate the activities which facilitate and improve processes occurring inside the enterprise. Therefore, the system relates to changes in the areas of technology, organization (of production), work safety and environmental protection. Its goal is to save time and cash, improve quality, workplace and the final product as well as to improve safety and activity towards the environment. The general regulations specify that the author of a suggestion can be an employee or a group of people who are production workers. The solution to the problem should be the idea proposed by the author or authors rather than the implementation of the official orders from the manager. All 
the ideas that meet formal determinants of suggestions are placed in the respective database. Within a month, the appointed team evaluates the suggestion while taking various areas into consideration: safety, ergonomics, efficiency, quality, environment and costs. If an idea is accepted, the originator (or several originators) obtains adequate remuneration, with the maximal level of 4,000 PLN. The suggestions systems have been used for already many years in two first enterprises, and in third enterprise it was implemented only in 2012 which will be reflected by further comparisons [10].

\section{RESULTS}

Figures 1-2 show the structure of employment in the companies surveyed with division into age and working experience. The individual enterprises are referred to as En1, En2, En3. It can be observed that these structures, despite minor differences, are similar. It should be remembered that the age and work experience are correlated with each other. More men are employed in all the enterprises, with women working mainly in offices. This is related to the specificity of the sector, because it is mainly manual work, which is one of the heaviest.

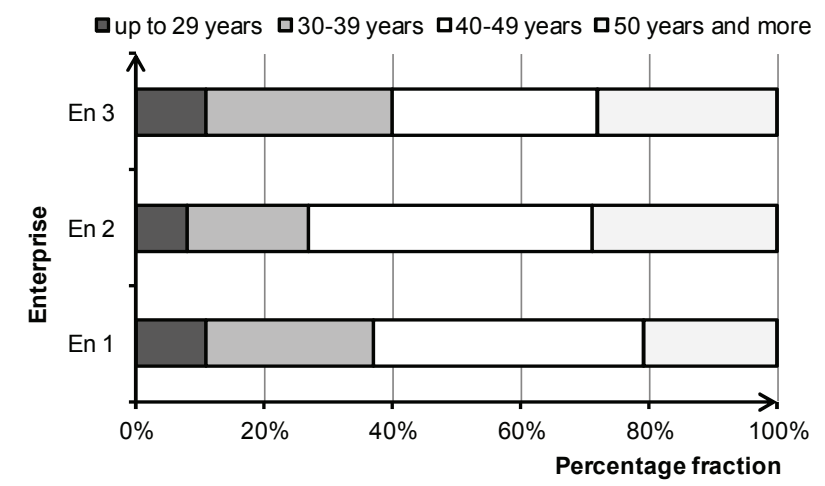

Figure 1 Characteristics of respondents - age [own study]

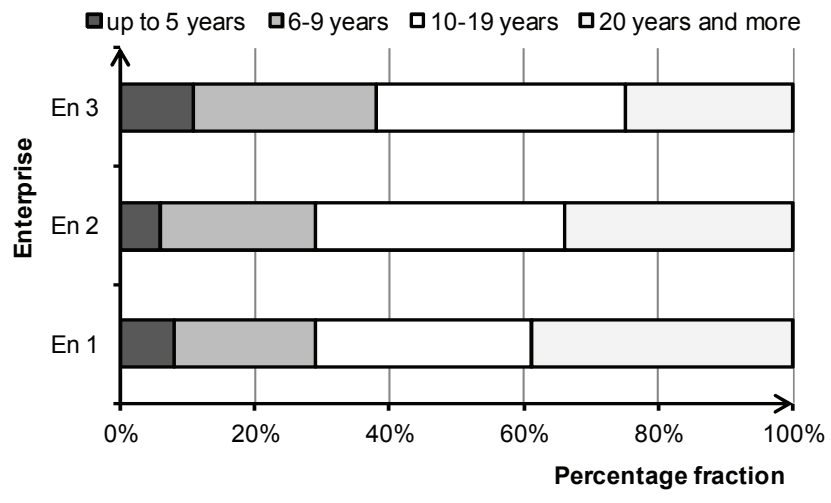

Figure 2 Characteristics of respondents - work experience [own study]

Figure 3 presents a general number of suggestions in 2013-2018. It can be observed that the Suggestions System in the case of the enterprise 3 just started to operate, since in 2013, employees made only 9 suggestions but year by year, this number was increasing. The Suggestion system was implemented in this enterprise in 2012. It can be concluded that in the beginning, employees either were not familiar with the system or they did not know how it operated. It is likely that in the beginning, they were unwilling to come up with ideas since they did not believe the system could work effectively. A similar growing trend was observed in the other two enterprises. But the number of these cases at the beginning of the period studied was much higher due to the efficiency of the system. The annual mean was 43.3 suggestions in enterprise 1,44 suggestions in enterprise 2 , and 26.5 suggestions in enterprise 3.

Figures 5-6 present a comparison of the suggestions with division into individual age groups in individual enterprises. A percentage comparison was also made. No comparison was made with division in terms of work experience since this characteristic is largely correlated with the employee age.

In enterprise 1, most of the suggestions were submitted by employees aged 30-39 and 40-49 years. However, it should be emphasized that these two groups were the most numerous in terms of employment, especially the latter age group. Therefore, calculated per employee, most suggestions were made by employees aged 30-39 years. 


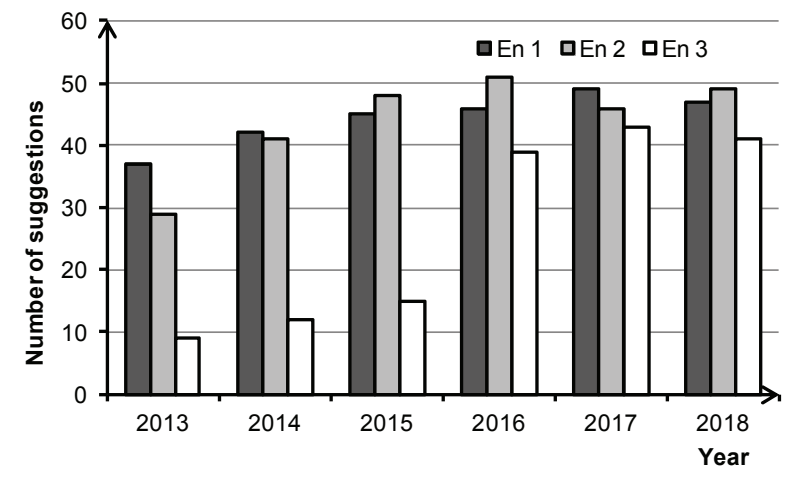

Figure 3 The number of suggestions in individual enterprises [own study]

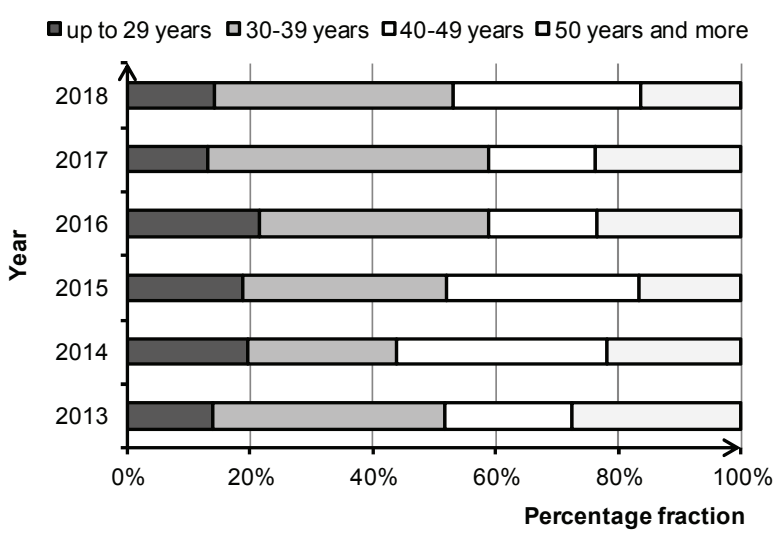

Figure 5 Percentage of suggestions by age of employees - En 2 [own study]

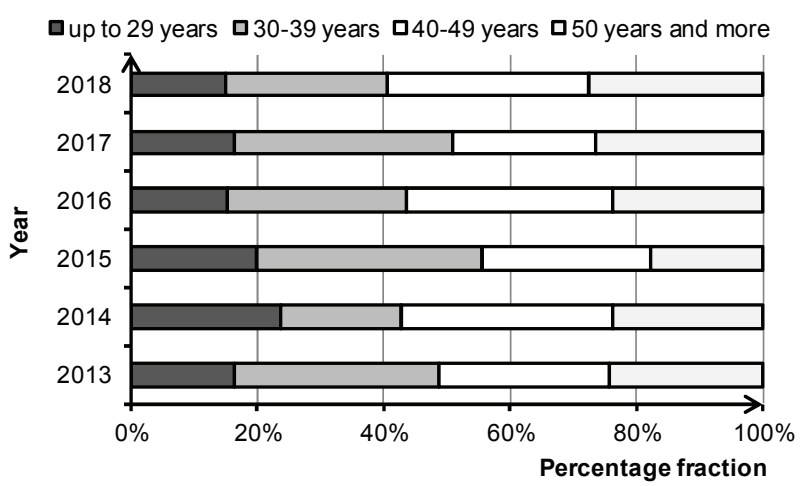

Figure 4 Percentage of suggestions by age of employees - En 1 [own study]

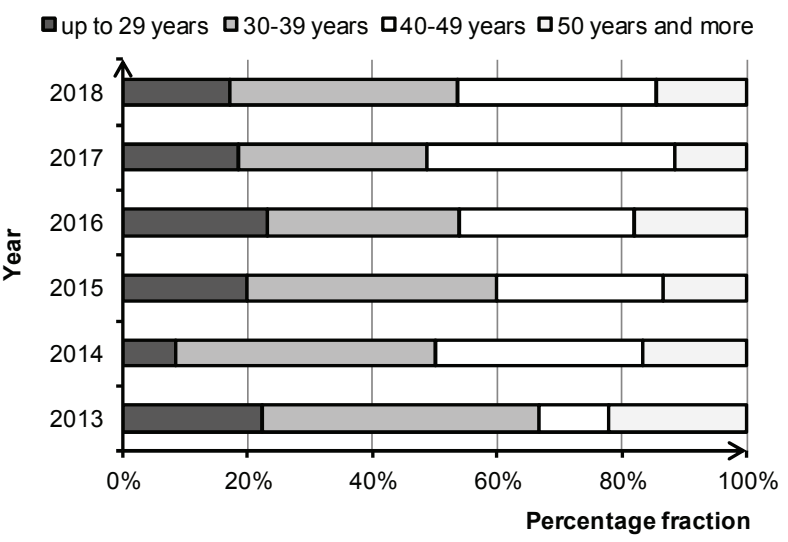

Figure 6 Percentage of suggestions by age of employees - En 3 [own study]

In enterprise 2, most suggestions were made by employees aged 30-39 years, although the number of employees was small. The advantage of this group was observed for all years. It is also the most active group per employee.

In the case of enterprise 3, a similar situation was observed for enterprise 1, the age group of 30-39 years submitted the most suggestions and a slightly less was found for the age group of 40-49 years. The second group was minimally larger, and, the group of employees aged 30-39 years was once again predominant per employee.

In all three companies, the youngest employees made the fewest suggestions. This can be explained by their small number in the structure, and, first and foremost, their low experience. However, in order to introduce improvements and propose new solutions, one needs knowledge and proficiency in performing work.

It can therefore be assumed that people employed in the steel sector under the age of 40 years are the most involved in rationalization activities. Perhaps this is due to the fact that they associate their future with the enterprises they work for. With the proposed solutions, they can help develop this enterprise and become a part of it. Perhaps they are just more open to changes and improvement than their older colleagues.

\section{CONCLUSION}

The paper analyses the Suggestions Systems, which operate in three Polish enterprises from the steel sector. The research is particularly important for this sector since there are no studies in the literature concerning this 
topic. The implementation of the system is needed in these enterprises due to the condition of the equipment used in this sector, the continuous pattern of their operation and high costs of modernization of production equipment.

In enterprises 1 and 2, the Suggestions Systems have already been developed, which can be indicated by the high and growing number of suggestions submitted by employees. In enterprise 3 , this system was being implemented in 2012, as indicated by the low number of suggestions made at the beginning of the period studied.

The most suggestions were submitted by younger employees, aged 30-39 years, followed by those aged 4049 years. Older employees were less involved in the Suggestions System. The least suggestions were submitted by the youngest employees, up to 29 years of age, mainly due to their small experience related to the processes conducted by the enterprises studied.

In summary, the Suggestions System is very important for organizations because it offers saving costs and focuses on innovative activities. Today, employee ideas and innovations are extremely important in any organization, since employees work, facilitate, monitor and improve their processes while they see that their ideas bring results and feel motivated to work. This system seems to be also very useful in typical research areas (e.g. strict materials science [11-13], coatings [14-16], image analysis of microstructures [17,18]) as well as industrial activities (e.g. rolling mills [19], steel hardening [20], biomass combustion [21], construction [22], management [23-25], blast-furnace [26-27]).

\section{REFERENCES}

[1] KLIMECKA-TATAR Dorota. Value Stream Mapping as Lean Production tool to improve the production process organization - case study in packaging manufacturing. Production Engineering Archives. 2017. vol.17, pp. 40-44.

[2] EDWARDS DEMING, W. The New Economics for Industry, Government, Education. 1st ed. Cambridge: The MIT Press, 1993. p. 266.

[3] MA, Jie, LIN, Zhibin and LAU, Chi Keung. Prioritizing the enablers for the successful implementation of Kaizen in China A fuzzy AHP study. International Journal Of Quality \& Reliability Management. 2017. vol. 34, pp. 549-568.

[4] MASSAKI I., Kaizen. Klucz do konkurencyjnego sukcesu Japonii. 1st ed. Kraków: Kaizen Institute Poland, 2007. p. 278.

[5] LASRADO Flevy and GOMIŠČEK Bojstan. A tool to measure maturity of an employee suggestion scheme. Management and Production Engineering Review. 2015. vol. 6, pp. 4-13.

[6] EFRAIMIDIS, Pavlos S., DROSATOS, George, ARAMPATZIS, Avi, STAMATELATOS, Giorgos and ATHANASIADIS, Ioannis N. A Privacy-by-Design Contextual Suggestion System for Tourism. Journal of Sensor And Actuator Networks. 2016. vol. 5, no. 10.

[7] Japan Human Relations Association (ed.). Kaizen Teian 1: Developing Systems for Continuous Improvement Through Employee Suggestions. 1st ed. Portland: Productivity Press, 1997. p. 218.

[8] NEAGOE Lavinia Nicoleta and MĂRĂSCU KLEIN Vladimir. Employee suggestion system (Kaizen Teian) the bottom-up approach for productivity improvement. RECENT. 2009. vol. 10, pp. 361-366.

[9] DZIUBA, Szymon T. and CIERNIAK-EMERYCH, Anna. Zróżnicowanie w podejściu do wykorzystywania systemu sugestii w przedsiębiorstwie produkcyjnym. Studium przypadku. In Striker M., eds. Problemy różnorodności w zarządzaniu. Łódź: Wyd. SIZ, 2017, pp. 77-88.

[10] INGALDI, Manuela, DZIUBA, Szymon T., CIERNIAK-EMERYCH, Anna and KADŁUBEK, Marta. The use of suggestion system for quality improvement in production enterprises in different countries. In $17^{\text {th }}$ Int. Scientific Conf. Globalization and Its Socio-Economic Consequences. Zilina: University of Zilina, 2017, pp. 391-398.

[11] KLIMECKA-TATAR, Dorota, PAWLOWSKA, Grazyna and RADOMSKA, Klaudia. The effect of Nd12Fe77Co5B6 powder electroless biencapsulation method on atmospheric corrosion of polymer bonded magnetic material. In METAL 2014: 23rd International Conference on Metallurgy and Materials. Ostrava: TANGER, 2014, pp. 985-990. 
[12] DUDEK, Aagata, WLODARCZYK, Renata and NITKIEWICZ, Zygmunt. Structural analysis of sintered materials used for low-temperature fuel cell plates. Materials Science Forum. 2010. vol. 638-642, pp. 536-541.

[13] WLODARCZYK, Renata, DUDEK, Agata and NITKIEWICZ, Zygmunt. Corrosion analysis of sintered material used for low-temperature fuel cell plates. Archives of Metallurgy and Materials. 2011. vol. 56, pp.181-186.

[14] KMITA, Tomasz and BARA, Marek. Surface oxide layers with an increased carbon content for applications in oilless tribological systems. Chemical and Process Engineering. 2012. vol. 33, pp. 479-486.

[15] KLIMECKA-TATAR, Dorota; BORKOWSKI, Stanislaw. and SYGUT, Piotr. The kinetics of Ti-1AI-1Mn alloy thermal oxidation and characteristic of oxide layer. Archives of Metallurgy and Materials. 2015. vol. 60, pp. 735738.

[16] BARA, Marek, NIEDZWIEDZ, Mateusz and SKONECZNY, Wladyslaw. Influence of anodizing parameters on surface morphology and surface-free energy of Al2O3 layers produced on EN AW-5251 alloy. Materials. 2019. vol. 12 , art. 695 .

[17] GADEK-MOSZCZAK, Aneta, RADEK, Norbert, WRONSKI, Sebastian and TARASIUK, Jacek. Application the 3D image analysis techniques for assessment the quality of material surface layer before and after laser treatment. Advanced Materials Research. 2014. vol. 874, pp. 133-138.

[18] GADEK-MOSZCZAK, Aneta, PIETRASZEK, Jacek, JASIEWICZ, Barbara, SIKORSKA, Sylwia and WOJNAR, Leszek. The bootstrap approach to the comparison of two methods applied to the evaluation of the growth index in the analysis of the digital x-ray image of a bone regenerate. New Trends in Computational Collective Intelligence. 2015. vol. 572, pp.127-136.

[19] SYGUT, Piotr, KLIMECKA-TATAR, Dorota and BORKOWSKI, Stanislaw. Theoretical analysis of the influence of longitudinal stress changes on band dimensions during continuous rolling process. Archives of Metallurgy and Materials. 2016. vol. 61, pp.183-188.

[20] SZCZOTOK, Agnieszka, RADEK, Norbert, DWORNICKA, Renata. Effect of the induction hardening on microstructures of the selected steels. In METAL 2018: 27th I International Conference on Metallurgy and Materials. Ostrava: TANGER, 2018, pp. 1264-1269.

[21] OPYDO, Michal, KOBYLECKI, Rafal, DUDEK, Agata and BIS, Zbigniew. The effect of biomass co-combustion in a CFB boiler on solids accumulation on surfaces of P91 steel tube samples. Biomass \& Bioenergy. 2016. vol. 85, pp.61-68.

[22] ULEWICZ, Robert and NOVY, Frantisek. The influence of the surface condition on the fatigue properties of structural steel. Journal of the Balkan Tribological Association. 2016. vol. 22, pp. 1147-1155.

[23] PACANA, Aandrzej, BEDNAROVA, Lucia, LIBERKO, Igor and WOZNY, Artur. Effect of selected production factors of the stretch film on its extensibility. Przemyst Chemiczny. 2014. vol. 93, pp. 1139-1140.

[24] PACANA, Andrzej, RADON-CHOLEWA, Anna, PACANA, Jacek and WOZNY, Artur. The study of stickiness of packaging film by Shainin method. Przemysł Chemiczny. 2015. vol. 94, pp. 1334-1336.

[25] PACANA, Andrzej, PASTERNAK-MALICKA, Monika, ZAWADA, Marcin and RADON-CHOLEWA, Anna. Decision support in the production of packaging films by cost-quality analysis. Przemysł Chemiczny. 2016. vol. 95, pp. 1042-1044.

[26] DULSKA, Agnieszka, STUDNICKI, Andrzej and SZAJNAR, Jan. Reinforcing cast iron with composite insert. Archives Of Metallurgy And Materials. 2017. vol. 62, iss. 1, pp. 355-357.

[27] BROZOVA Silvie, INGALDI Manuela, SPERLIN Ivan, Economical Aspects of High-Temperature Heating Utilization for Industrial Waste Treatment. In METAL 2014: 23rd International Conference on Metallurgy and Materials. Ostrava: TANGER, 2014, pp. 377-382. 